\title{
Local Wisdom in Banjarese Culture Perspective
}

\author{
Wahyu Wahyu \\ Lambung Mangkurat University, Banjarmasin, Indonesia \\ *Corresponding author. Email: wahyu@ulm.ac.id
}

\begin{abstract}
Local wisdom belongs to the local community. This local wisdom is lived, practiced, taught and passed on from one generation to another which at the same time forms the pattern of everyday human behavior, both towards fellow humans and towards nature. Local wisdom is noble values that are believed to be true, applicable in the local communities' life order and aim to protect and manage the environment in a sustainable manner. South Kalimantan is one of the cities that has a variety of local wisdom, both local wisdom that has been around for a long time passed down from generation to generation as well as local wisdom that has just emerged as a result of interactions with other communities and cultures. The current paradigm of modern science and technology has affected the loss of some of the local wisdom values. Therefore, all efforts to explore, discover, build and preserve the values of local wisdom become a necessity.
\end{abstract}

\section{Keywords: Banjarese, Culture, Local Wisdom}

\section{INTRODUCTION}

Indonesia is an archipelagic country, has thousands of islands and various ethnic groups. Communities on each island have their own characteristics in maintaining and utilizing their environment. There are very diverse ways of maintaining and utilizing the environment, also depends on environmental characteristics. For example, there are people who live on the banks of rivers, on the coast, on the edge of forests, in the mountains, and so on. The environment has shaped their behavior, in a way so that they can continue to grow, develop and adapt to their environment. They always take good care of their environment to better sustain their lives. In addition, they can also enjoy the results of their environment, such as agriculture, plantations, fisheries, animal husbandry. They are aware that the environment is a place for their activities and a place of survival. The contribution of the environment to the survival of the community in various regions in Indonesia has fostered local wisdom [1].

This local wisdom has given color to the Indonesian nationality. Each region has contributed in the national context. In fact, the various cultures in Indonesia have actually strengthened Indonesia. It can be seen that since 1928 , various youth organizations from various regions have established themselves as one unit [1]. Local wisdom refers to various cultural treasures that has grown and continued to develop in a society, are trusted and recognized as important elements that are able to strengthen social cohesion in the community [2]. This shows a great significance of the importance of local wisdom values and its position among the society. The value of local wisdom must be seen as a social heritage, believed to have a high value for the pride of a nation. Therefore, the transmission of local wisdom values to the next generation is a necessity.

In Law no. 32 of 2009 concerning environmental protection and management (PPLH), local wisdom can be interpreted as a value that applies in people's lives to protect and manage the environment so that it is sustainable. Local wisdom is used as a principle or basis when protecting and managing the living environment. South Kalimantan is one of the cities that has a variety of local wisdom, both local wisdom that has been there for a long time passed down from generation to generation as well as local wisdom that has just emerged as a result of human living interactions. The forms of local wisdom in the Banjar community can be in the form of values, norms, ethics, beliefs, customs (such as traditional ceremonies and rituals, marriages), manners in everyday life, rules for human relations with the environment (such as nature, animals, etc.). plants aimed at nature conservation efforts), local wisdom in the form of words of wisdom or philosophy (such as advice, proverbs, rhymes, folklore or oral stories), and so on. This local wisdom must be raised and preserved again, because local 
wisdom as it is, is the implicit identity of the region. Along with the increase in cultural information technology towards modern life and the influence of globalization, the heritage of the local community wisdom is facing the challenge of its existence. This condition has given rise to uncertainty, because information technology has radically changed the way of life, way of thinking, and patterns of relationships between people. When facing the swift globalization current that creates a vague cultural boundary, it is necessary to strive for cooperation based on Indonesian diversity. At the local level, this diversity is manifested in local wisdom as a pillar of the life of the local community. With advances in information technology, especially media technology in all walks of life, we should all be able to build awareness to reposition the space for local wisdom values. One of the efforts that need to be made in realizing local wisdom is to respond to changes in culture with local wisdom in a positive and differential manner.

Differential culture is flexible and can shape itself in various forms, dynamic and situational. According to [2], understanding culture must begin by redefining culture itself, not as a genetic culture (as a handed down guideline), but as a differential culture (which is negotiated in all social interactions). Culture is not something that is hereditary shared or practiced collectively, but becomes a more situational culture whose existence depends on the character of power and relationships that change from time to time. So, the efforts of local wisdom to face the challenges of cultural change are to respond to culture values differentially.

\section{THEORETICAL REVIEW}

\subsection{Understanding Local Wisdom}

Wisdom comes from the word wise. According to the Indonesian Dictionary, wisdom has two meanings, namely know or knowing. The second meaning is clever, intelligent, and wise. The word wise if you add the prefix "ke" and the suffix "an" in Indonesian language would mean wisdom, intelligence as something that is required in an interraction. The word local, which means a place or in a place where there is growth, life, and anything that may be different from other places or a place of value which may apply locally or universally [3].

Etymologically, the local wisdom mentioned is called Local Wisdom, Local Knowledge, and Local Intelligence. From the etymological aspect, local wisdom is knowledge that has emerged from a long period of time that evolved together with the community and their experiences in a local system environment. The long evolutionary process to which its existence is very much inherent in society has the potential to create the energy source of the community's collective knowledge system in order to live together dynamically and peacefully [4].
This understanding sees local wisdom not only as a reference for individual or collective behavior, but further, namely being able to dynamize people's lives that are full of civility. Substantially, local wisdom basically contains values, perspectives of the people who follow it, which are dynamic and not static which tend to change from time to time. Values that are believed to be true and become a reference in the daily behavior of the local community. The emergence of local wisdom in society is the result of a long process of various kinds of empirical and non-empirical knowledge. The results of this thought reflect the original science and technology of the community which is often referred to as local culture (local wisdom), such as local wisdom in agriculture, health, food supply, education, processing of natural resources, and various other activities.

Some experts mention local wisdom with the following definition:

1. [5], local wisdom is defined as wisdom in the traditional culture of ethnic groups. Wisdom in a broad sense is not only in the form of cultural norms and values, but also all elements of ideas, including those that have implications for technology, health care, and aesthetics. With this understanding, what is included as the elaboration of local wisdom is the various patterns of action and the results of its culture.

2. [6], the term local wisdom is the result of the translation of local genius which was first introduced by Quaritch Wales in 1948-1949 which means local culture ability to deal with foreign cultural influences when the two are collided with each other.

3. Vlaenderen (1999), describes indigenous knowledge as a collection of ideas and assumptions that are used to guide, control and explain actions in a specific setting based on a value system (religion and cult believes) and epistemology. He also further explained the meaning of indigenous knowledge system as knowledge owned and controlled by indigenous people in a systematic way [7].

4. Brouwer (1998), describes traditional knowledge as ancient abilities, original and special customs, conventions and routines that embody a static view of people's culture [7].

5. Kajembe (1999), describes indigenous technical knowledge including knowledge of tools and techniques for assessment/assessment, skills, changes in form and utilization of specific resources for certain locations [7](Muyungi and Tillya, 2003).

6. Regarding the characteristics of local wisdom, [8], mentions several things including:

1. It is a collection of experiences, and is rooted in and produced by people living in a specific place;

2. Transmitted orally, by imitation and demonstration; 
3. Is a consequence of direct practice in everyday life and is continuous and strengthened through experience and trial and error;

4. Tend to be empirical rather than theoretical knowledge in the narrow sense;

5. Repetition is a hallmark of tradition, even as new knowledge is added;

6. Always changing, produced and reproduced, found and lost, often represented as something static;

7. Distinctive;

8. Distributed socially unequally;

9. Functional in nature;

10. Holistic, integrative and embedded in the wider cultural tradition.

Based on the above definition, it can be said that local wisdom includes traditions and practices that have been going on for a long time and developed in a certain area, originating from a spefic place or local community. Local wisdom is usually reflected in the long-standing habits of people's lives. The sustainability of local wisdom is reflected in the values that apply to certain community groups. These values become the grip of community groups and become an inseparable part of their daily lives and can be manifested in the form of customs, rules/norms, culture, language, beliefs and daily habits.

\subsection{Value of Local Wisdom}

Every society essentially has a set of social and cultural values that can be positioned as social capital (Social Capital). The attitudes and behaviors of traditional people, because they are based on values that are believed to be true and this is a form of local wisdom. Gobyah [9] interprets local wisdom as a truth that has been traditional or steady in an area.

Values in socio -cultural relations are concerned with the price of promptness or the price of goodness, which can be said to be important and insignificant, or even deep and superficial, but such qualifications cannot be measured quantitatively [5].

In everyday life human beings interact guided by values and limited by social norms. Value as something useful, good and considered important by society. Something is said to have value, when it has usefulness, truth, goodness, beauty, and religiosity. Values and norms are two things that are interrelated and very important for the realization of a society order. This order can be realized if members of the community behave and behave in accordance with and in accordance with applicable values and norms. Therefore, if the traditional values that exist in the community are rooted in local cultural roots, then the community will lose its identity and identity, as well as lose a sense of pride and a sense of belonging. Efforts to dig, discover, build and transmit norms, morals and values come from local excellence because its wisdom becomes a necessity.

The content of values in a form of culture is abstract and is often vague and hidden. In this context, there are several values of local wisdom, namely:

1. Knowledge belonging to the local community. There is no individual knowledge of local wisdom. Knowledge of local wisdom is owned and shared collectively for fellow community members. It is open to be known, even to be taught openly to be owned and lived by all members of the community. Here are the values of kinship and respect.

2. Manage the environment well. Knowledge of local wisdom is knowledge of how to live well with all the contents of nature. This knowledge also includes how to treat every part and life in nature in such a way, both to maintain the life of each species and to maintain all life in the universe itself. All of them have provisions as practical knowledge and norms that guide their implementation.

3. Nature is full of values and moral messages. Local communities and the nature itself are not seen solely as objects and tools for human interests. Nature sends moral messages and commands for humans to obey, including moral messages in the form of a respect for life. Because nature is relative, in it there are values that must be obeyed.

4. Moral activity. Farming, hunting and fishing are not just scientific activities in the form of applying scientific knowledge, which is guided by rational scientific principles and understanding. These activities are moral activities that are guided and based on moral principles or taboos originating from local wisdom. These activities are not all, only some of which can be explained rationally according to the size of science. It can only be understood within the framework of local wisdom. For example, some villages in West Java, when they are about to start planning or cutting rice, are often preceded by prayers and offerings (serving types of food). This cannot be explained scientifically rationally. All of this can only be understood within the framework of the embodiment of local wisdom, namely humans, nature and the relationship between them and nature. This can only be understood in the context that their activity is a moral activity [10].

From this it can be concluded that the practice of local wisdom is very valuable and has benefits for human lives. The practice of local wisdom views humans as an integral part of nature and has a relationship with all creatures in the universe. They never try to live a life that is only concerned with relationships with others, but also relationships with the surrounding natural environment: with forests, the sea, lakes, rivers, mountains and with 
animals and plants in nature. Therefore, it can be understood that the practice of local wisdom is an effort by local communities to manage environmental quality. Environmental quality is only associated with environmental problems, such as pollution, erosion and flooding. Good environmental quality can be interpreted as environmental conditions in relation to quality of life. The higher the degree of quality of life in a given environment, the higher the degree of the environmental quality and vice versa.

\subsection{Banjarese Local Wisdom}

South Kalimantan has a lot of cultural wealth. Thus, it is important to explore local wisdom related to its meaning and function for current and future conditions. The pattern of life of the people of South Kalimantan, especially for the Banjar tribe, almost $80 \%$ from upstream to downstream is marked by a distinctive culture, namely river culture. On the other hand, this is different from agrarian culture or inland (mainland) culture which has a strong awareness of land ownership. In South Kalimantan, since ancient times, rivers have been understood as the main traffic lanes between one area and another, so Banjarmasin is often dubbed the River City or the City of a Thousand Rivers. [11].

In subsequent developments, Banjarese culture undergo a process of acculturation, mixing with other cultures such as Dayak culture, Javanese culture, Malay culture which were wrapped into one in Banjar cultural clothes [11]. Thus, Banjar culture has a democratic character. This is marked by the very openness and flexibility of Banjar culture to accept other cultures that were originally foreign. It is able to place these other cultures as equal partners and equal dialogue partners in his locus. In this way, the Banjar people are egalitarian, equal and democratic and far from tribal fanaticism. The values of local wisdom in Banjar culture can be called in several forms, including:

\section{The Tradition of Deliberation and Justice}

Democratic values began when Sultan Suriansyah (1526-1545) as the first king of the Banjar kingdom governed his administration. The first step taken by the Sultan was not to choose the posts of Patih and Mangkubumi from the nobility belonging to the royal family, but rather from Urang Jaba (ordinary people) who were capable, had high abilities and loyalties to the kingdom. The first person who was elected as king by the will of the general people at that time was Patih Masih, a fisherman's son on the banks of the Martapura river, precisely in the Kuin area. Likewise, the tradition of justice in the Banjar community has long been developing. There is a kind of justice institution called the Syar'iyah Court which is lead by a Mufti. The task of the Mufti is to provide a fatwa for those who want to carry out the legal process by showing a proof letter with a stamp or the legality of the Sultan's signature [11].

2. Mutual Aid Tradition

The tradition of gotong royong as a feature of democracy also lives in Banjar society. There is a well-known expression that becomes the lifeline of the Banjar people; Gawi Sabumi Until Manuntung (work together until complete) or Waja Sampai Kaputing (work together from beginning to end) or Kayuh Baimbai (paddle in unison). This means that in carrying out the work until it is finished by working together, rambate rata hayu, the sleeves are rolled up, the weight is put across shoulder and the light is carried together.

\section{The Tradition of Freedom}

Since childhood, Banjar children have been trained and educated by their parents to be free to choose their own path in life so that they can become independent quickly. This is closely related to the strong trading culture of the Banjar people. The freedom mentioned is more towards the economic field. Some were invited to do small trades, just to help their parents sell, learn to work odd jobs by choosing modest rewards, some were warned about the ins and outs of trading. Some of the others, were given a choice and financial means to continue their education to their heart's content. For the Banjar people, what is important is not wanting to trade or going to school, but how fast they can let go of dependence on their parents and be free and independent themselves.

\section{The Tradition of Criticism}

The tradition of criticism in Banjar culture is mostly expressed in artistic expressions. First, in Madihin art, one of the most popular traditional arts of the Banjar people is often chanting the poems of Pemadihin (now very famous John Tralala and his son Hendra) by inserting scathing criticism on anyone who is pretentious with a great sense of subtle satire wrapped in rhyme language, beautiful, poetic and humorous in the form of a dialogical reply or replying to a familiar Baturai rhyme with the rhythm of the so-called flying drum (a kind of tambourine). Second, in the legend of the Palui story, which is faithful to be present in the Banjarmasin Post newspaper (the newspaper with the largest circulation in Banjarmasin). This character is somewhat similar to the character of Kabayan in West Java, which is described as a funny human figure who is naive, naughty, unique, a little bit smart and stupid, a bit stupid smart, and a bit brave and afraid. He appears as a critic of anyone he deems excessive and arrogant.

\section{Knowledge of Natural Symptoms}

The Banjar people learn natural phenomena through plants, animals and the stars in the sky. Various natural events are always experienced in the cycle of 
time, which sometimes occurs repeatedly and finally the symptoms can be calculated.

According to SR [12], traditional Banjar people usually know natural phenomena by observing plants, animals and stars in the sky. For example, when the ambawang (embacang) tree begins to flower, they believe that summer has arrived. This ambawang tree is a typical Banjar fruit tree. If the flowers of this ambawang tree are dark red, then this indicates the tree will last a long time, but if it is pink, it means that the dry season will not last long.

\section{Knowledge of Physical Environment}

The people of Banjar can find out the conditions and layers of the soil based on the plants that are on it. This is based on existing knowledge and from life experience in the community. According to SR [12], Banjar people can determine soil fertility based on their experience. Soil is said to be fertile if there is a source of water at the bottom. Clay and a thick layer of loose soil, this is usually referred to as tuha soil. Soil types that are declared suitable for agricultural land are often called cold soils. Other knowledge is also often used by the community to find out whether or not land is good for agriculture, for example to determine soil fertility by looking at the types of plants that grow on it. Soil is classified as fertile soil if it is grown with the types of belaran grass, kusisap, pipisangan and lembiding spikes so that the land is good for agricultural land, but if it grows like parupuk, purun tikus, kumpai miang, benderang, dan hahauran, then the land is considered as not fertile.

7. Knowledge of Plant Types, Benefits and Cultivation

The knowledge of the community about plants, or whether if plants that accompany rice planting in the fields, is deemed quite good and wise. The existing shipyard system is planted with cucumbers, watermelons, corn and other creeping plants that can function as a control tool against plant pests and mice, which can be identified by examining the plants grown in the shipyard. Therefore, the plants that are planted are specifically chosen are those preferred by rats so that it is easy to know if the rice fields have rats. This method has proven to be very helpful in preventing them.

The living environment found in the yard of the house is often planted with perennials such as langsat trees for borders with leaves that are very strong and do not fall easily so they do not pollute the yard. In addition, he is also planted with medicinal herbs such as lemongrass, galangal, janar, jeriangau and rarely grows taro and sweets because they like to be visited by rats and it become their hiding house. The same applies to trees or plants (the rambutan tree, kariwaya, which is believed to be a place of refuge for the spirits (unseen creatures) of the Banjar people who do not want to plant them near their homes).

The nature surrounding the household can provide benefits for us as a coloring agent used for food and beverages which can then be used as a dye in the manufacture of sasirangan fabrics for generations. RD [12] mentions that dyes can be taken from various types of plants around our environment, such as yellow from janar and temulawak plants. Red comes from gambier and mingkudu fruit, kesumba or red lombok. Green comes from pudak or ginger leaves (tipakan). Black comes from kabuau or uar. Purple comes from the seeds of ramania (gandaria) or karamunting fruit. Chocolate comes from the outside or the skin of the rambutan fruit. The use of dyes derived from this plant is a local wisdom that is friendly to the environment and does not harm human health.

\section{Traditional House / Traditional Ceremony}

South Kalimantan has various kinds of traditional houses, namely as many as 11 (eleven) types of Banjar traditional houses which can be described as follows :

a. Adat Banjar House Bubungan Tinggi Type;

b. Tipe Gajah Baliku;

c. Gajah Manyusu;

d. Balai Laki;

e. Balai Bini;

f. Palimasan;

g. Palimbangan;

h. Anjung Surung;

i. Tadah Alas,

j. Joglo; and

k. Lanting

Banjar traditional houses have their own specifications, both in terms of building construction and social historical background. According to SYR [12], the Banjar tribal community has a traditional house called Rumah Banjar from construction which is always in the form of a house on stilts. This type is an environmentally friendly type because the land can function as a water catchment so that it can overcome flooding. This type of house on stilts by the local government has been used as a regional regulation in the construction of houses and shop houses. Likewise the construction of poles and sticks with a Kacapuri system that still allows water to flow. Banjar traditional houses have doors that are quite wide. This is intended to facilitate air circulation so that the house is always cool and fresh.

The Banjar tribe also has a house called Rumah Lanting, which is a traditional Banjar house located on a river because the river was the main means of transportation in the past. The lanting house, apart from being used as a place to live, also functions as a barrier to river shore erosion 
because the lanting can anticipate waves. The existence of lanting as a river tourist attraction needs to be arranged neatly with an interesting architectural touch.

\section{CONCLUSION}

The local wisdom of the Banjar people continues to grow and becomes part of Banjarese culture. It plays an important role in its development, including managing the environment containing moral values and messages, responsible behavior, respect and care for the environment. All of this should be understood in terms of environmental quality. The higher the quality of the environment, the higher the quality of life of the community in that particular environment.

There are many local wisdoms whose existence is still maintained in South Kalimantan, such as: the tradition of deliberation and justice, the tradition of mutual cooperation, the tradition of freedom, the tradition of criticism, knowledge of the physical environment, knowledge of types of plants, their benefits and cultivation, and traditional Banjar houses.

\section{REFERENCES}

[1] dkk Rochgiyanti, Kearifan Lokal Orang Dayak Bakumpai di Lahan Basah. Yogyakarta: Aynat Publishing, 2014

[2] irwan Abdullah, Konstruksi dan Reproduksi Kebudayaan. Yogyakarta: Pustakan Pelajar, 2010.

[3] M. Fahmal, Peran Asas-asas Umum Pemerintah yang Layak Dalam Mewujudkan Pemerintahan yang Bersih. Yogyakarta: UII Press, 2006.

[4] A. F. Diem, "Wisdom of The Locality (Sebuah Kajian: Kearifan Lokal dalam Aritektur Tradisonal
Palembang)," Berk. Tek., vol. 2, no. 4, 2012.

[5] E. Sedyawati, Budaya Indonesia, Kajian Arkeologi, Seni dan Sejarah. Jakarta: Raja Grafindo Persada, 2006.

[6] A. Rosidi, Kearifan Lokal dalam Perspektif Budaya Sunda. Bandung: Kiblat Buku Utama, 2011.

[7] Muyungi \& A.F. Tillya, Appropriate Institutional Framework for Coordination of Indigenous Knowledg. LINKS Praject Gender, Biodiversity and Local Knowledge System for Food Scurity., 2003.

[8] Ellen $\mathrm{R}$ and Bieker, Introduction dalam Ellen R. P. Parker and A Bicker (Ed). Indigenous Environmental Knowledge and its Transformation Critical Antropological Perpectives. Francis: The Taylor \& Francis e-Library, 2005.

[9] S. Ernawi, "Harmonisasi kearifan lokal dalam Regulasi Penataan Ruang (Online), Makalah pada Seminar Nasional 'Urban Curture, Urban Future, Harmonisasi Penataan Ruang dan Budaya Untuk Mengobtimalkan Potensi Kota,” 2010. [Daring]. Tersedia pada: http://www.penataanruang.net.

[10] A. S. Keraf, Etika lingkungan hidup. Jakarta: Penerbit Buku Kompas, 2010.

[11] H. Abdussami, "Budaya Banjar dan Nilai-nilai Demokrasi. Banjarmasin," 2014. .

[12] Abidinsyah, Internalisasi Nilai Peduli Lingkungan Melalui Pembelajaran Berbasis Kearifan Lokal (Studi di SDN Antasan Besar 7 Banjarmasin). Banjarmasin: Disertai (Tidak Dipublikasikan), 2012. 